\title{
Gauging the Processing Times of Ambiguous Sentences: A Reaction Time Study on Persian Undergraduate Students
}

\author{
By Mohammad Salehi* \\ Nasim Mahboob Basiri ${ }^{\dagger}$
}

The present study explored the differences among the process times for sentences containing one of the three kinds of linguistic ambiguities namely, lexical, grouping, and functional ambiguities. A reaction time program of a 30item multiple-choice test of translation was developed. Forty-three Persian undergraduate students took the test. The reaction time of each item was recorded in milliseconds for each participant. A multivariate ANOVA (MANOVA) was run to compare the process times for each subsection of the test. The results of the pair-wise comparison tests indicated that there was a significant difference between process times for lexical and grouping ambiguities and between those of lexical and functional ambiguities. There was no significant difference, however, between the process times for grouping and functional ambiguities. The findings of this study can be useful in educating English learners about ambiguities and deciding on which ambiguity should be under more focus and attention.

Keywords: functional ambiguity, grouping ambiguity, lexical ambiguity, processing time, reaction time

\section{Introduction}

Ambiguity is a general term to describe words, phrases, or sentences with more than one meaning (Fromkin, Rodman, \& Hyams, 2013). Linguistic ambiguity falls into some categories the two most important of which, according to Hudson (1999), are lexical ambiguity and structural ambiguity, with the latter one falling into two categories: Grouping ambiguity and functional ambiguity. Akmajian, Demers, Farmer, and Harnish (2001) define lexical ambiguity as a situation when a word can have more than one meaning. For example, in "he picked up a date" the word "date" can be a fruit or a significant day. According to Hudson (1999), grouping ambiguity is a subcategory of structural ambiguity in which a sentence has more than one meaning due to different groupings of the constituents. For instance, in the phrase, "the brother of Ann and Sarah will go to the party", even though each word is unambiguous by itself, the whole meaning of the sentence seems to be

\footnotetext{
* Assistant Professor, Sharif University of Technology, Iran.

${ }^{\dagger}$ Sharif University of Technology, Iran.
} 
ambiguous, as we cannot be sure whether the brother of Ann and Sarah as a single person is going to the party or if the brother of Ann as well as Sarah are going to the party. In such cases, it is possible to draw a different tree diagram for each different grouping. Furthermore, Hudson defines functional ambiguity as the other subcategory of structural ambiguity arising when some constituents of the sentence can have different functions, and these different functions cause different meanings. Take as an example, "John is too far away to see". In this sentence, John can be either the subject or the object of the sentence, giving rise to two different meanings. In such cases, it is not possible to draw more than one tree diagram. According to MacKay (1996), the sentences containing an ambiguous word are processed slower than unambiguous sentences. There have been some studies probing the ambiguity processing patterns using different experimental tasks such as click detection (Garrett, Bever, \& Fodor, 1966), self-paced listening (Waters \& Caplan, 2004), eye tracking (Kamide, Altmann, \& Haywood, 2003), moving window self-paced reading (Just, Carpenter, \& Woolley, 1982), and maze tasks (Forster, Guerrera, \& Elliot, 2009). There seems to be a gap in the literature, however, regarding the use of one of these tasks to explore the differences among the processing times for sentences containing one of the three different kinds of the above-mentioned ambiguities. Accordingly, the current study utilized a reaction time program, a multiple choice test of translation recording the reaction time on each item, to investigate the differences between the three mentioned kinds of ambiguities namely, lexical, grouping, and functional ambiguities, in terms of the time needed to process a sentence containing one of them.

\section{Literature Review}

Processing research is very common in the second language acquisition research. There have been studies concerning aspects of second language that were exposed to research. For example, Salehi (2011a) investigated whether the processing of pied-piping and preposition stranding is a function of a proficiency level of learners. In addition, Salehi and Bagheri (2014) investigated the effect of the response format on grammaticality judgment. Processing ambiguous sentences is another promising area for research.

Ambiguity is an inevitable phenomenon in language that can be considered a functional property of language allowing more efficiency in communication (Piantadosi, Tily, \& Gibson, 2012). At the same time, ambiguity could be a source of difficulty in processing sentences by readers specifically for those reading these kinds of sentences in a language other than their first one. Moreover, it could cause miscommunication especially between native and non-native speakers of a language. Another ambiguity-related problem worth mentioning is that of interpreting a grammatical sentence as ungrammatical due to grouping ambiguity in the so called garden-path sentences (Altmann, 1998). As MacKay (1996) puts it, sentences containing an ambiguous word are processed slower than unambiguous sentences. This is true about other kinds of ambiguities such as grouping and functional ambiguities as well. MacKay and 
Gass (2005) consider the reaction time study as a subcategory of processing research and that measuring the time needed for a sentence to be processed or to be responded to, usually in milliseconds, is based on the assumption that sentences with more complex syntax and specifically containing ambiguities, require more processing time and that "the more time it takes to respond to a sentence, the more processing "energy" is required" (p. 62). It can therefore be stated that the processing difficulty that linguistic ambiguities can cause is generally measured based on the processing time of the sentence containing that kind of ambiguity. What follows is a brief review of the studies attempting to measure the processing load of sentences containing different linguistic ambiguities.

Lexical ambiguity has been the focus of most of the linguistic ambiguityrelated researches. For instance, Simpson (1981) investigated the processing of ambiguous words via two experiments. In the first experiment, lexical decisions were made to words related to the dominant or the subordinate meanings of homograph primes. In the second experiment, however, ambiguous words ended sentences varying in the degree to which they biased the dominant or subordinate meaning of the homograph. After ambiguous sentences, dominant meanings were retrieved first. According to the findings of this study, dominance and context make independent contributions to the processing of ambiguous words.

Seidenberg, Tanenhaus, Leiman, and Bienkowski (1982) conducted five experiments on the processing of ambiguous words in sentences, with two categories of ambiguous words (noun-noun and noun-verb) and two types of contexts (priming and nonpriming). They found that the participants consistently accessed multiple meanings of words and selected one reading within $200 \mathrm{msec}$. The results of their study suggest that meaning access is an automatic process unaffected by knowledge-based processing, and that selective or multiple access of the meaning observed largely depends on the structure of the ambiguous words, not the nature of the context.

Moreover, Duffy, Morris, and Rayner (1988) recorded the eye movements of the readers, as they were reading sentences that contained lexical ambiguous or unambiguous words. The words with lexical ambiguity fell into two categories, namely ambiguous words with two equally likely interpretations (equibiased words) or with highly dominant interpretation (non-equibiased words). The results of their study indicate that gaze duration on the target word and reading times on the later parts of the sentences depend on the type of the target word that is ambiguous, namely equibiased or non-equibiased, and the location of the disambiguating clause. Their findings affirm that more than one meaning of an ambiguous word is automatically activated. The degree of this activation, however, is influenced by frequency and context.

Furthermore, Papadopoulou (2005), in a review of the studies regarding ambiguity resolution strategies used during processing a second language, suggested that most of the research findings indicated that even advanced learners of a second language were slower readers than the native speakers and 
that they used processing strategies far from those appropriate for processing language input. Furthermore, L2 learners, despite their sensitivity to lexical cues while processing the input, were less likely to apply structural information on line. According to this review, however, the transfer of processing mechanisms from L1 to L2 as well as the effect of L2 exposure on adopting second language processing routines needed more investigation.

Another study conducted by Sheridan and Reigngold (2012) investigated the time course of ambiguity processing by examining the distributional analyses of first-fixation durations on 60 biased homographs each read twice, once in a subordinate-instantiating context and another time in a dominantinstantiating context. Their results revealed that the contextual manipulation had a fast-acting influence on most of the fixation durations.

Tokowicz (2014) considered lexical ambiguity and part-of-speech ambiguity as a source of translation ambiguity that is the situation when a word in one language can be translated into more than one word in a target language. Translation ambiguity, according to her, affects language processing, learning, and representation.

Tokowicz and Kroll (2007) examined the effect of translation ambiguity on translation production through a task in which the participants were presented a word in one language and were required to translate it into a target language. Having investigated both the accuracy of responding and the time it took in milliseconds as the token of processing difficulty, they found out that ambiguous words were processed more slowly and less accurately in comparison to the unambiguous words.

In another study, Eddington and Tokowicz (2013) focused on the effect of the context, in the form of a prime word, on the processing of two different types of ambiguous words by English-German bilinguals: Form-ambiguous words and meaning-ambiguous words. The former ambiguity is due to nearsynonymy, while the latter is due to multiple meanings. They found that related primes reduced the processing speed of the ambiguous words, but did not eliminate the translation ambiguity disadvantage. Furthermore, they found priming only for meaning-ambiguous words.

Another study conducted by Laxen and Lavaur (2010) also examined the translation ambiguity disadvantage in the translation recognition tasks with French-English bilinguals to show that, in line with Tokowicz and Kroll's (2007) findings, ambiguous words had longer reaction times than unambiguous words. This proves that the translation ambiguity disadvantage is not limited to the production tasks. Similarly, through examining the role of translation ambiguity through a translation recognition task completed by highly proficient Spanish-Catalan and Catalan-Spanish bilinguals, Boada, Sánchez-Casas, Gavilán, García-Albea, and Tokowicz (2013) found a disadvantage for translation-ambiguous words.

As mentioned earlier, translation ambiguity is believed to affect language learning especially in its initial stages. Degani and Tokowicz (2010), in an attempt to address this very issue, taught a set of Dutch words to English speakers who had no prior knowledge of Dutch. Some of these words were 
ambiguous, half of which form-ambiguous, and the other half meaningambiguous. They found that ambiguous words were translated less accurately than the unambiguous words and that the translation-ambiguity disadvantage was larger for the form-ambiguous words.

Moreover, Snedeker and Yuan (2008) explored how adults and children combined information about the prosodic structure of an utterance and information from individual words to interpret sentences with structural ambiguities. They tested four to six -year- old children and adults using the visual world paradigm; and with the finding, that the fixation patterns in both groups were affected by lexical cues by around $200 \mathrm{~ms}$, with the prosody manipulation affecting this early time window in adults, while this effect was delayed around $500 \mathrm{~ms}$ in children. They reported that the effects of lexical and prosodic cues were almost additive. This means that prosody affects the interpretation of utterances with strong lexical cues and lexical information affects utterances with strong prosodic cues. In general, children, as well as adults, can use both information sources to resolve structural ambiguities.

In a study conducted by Kail, Lemaire, and Lecacheur (2012), French youngsters and adults were asked to detect grammatical ambiguities in sentences as fast as they could, while their detection times were recorded for the analysis as a function of age and sentence characteristics such as ambiguity type and position. As a result, these researchers claimed that using linguistic cues in the online process was somehow independent of the age, but loss of cognitive resources with age showed a cost of using cues and more use of the context.

Moreover, Joseph and Liversedge (2013) conducted two experiments in which children and adults read sentences with a temporary syntactic ambiguity; their eye movements were monitored during this task. The first experiment involved participants reading sentences with a manipulated attachment of a prepositional phrase. The second experiment, on the other hand, involved participants reading sentences with a manipulated attachment of an adverbial phrase. As a result, these researches reported that the adults and children showed similar processing preferences; however, children had delay in detection of initial syntactic misanalysis compared to adults. The overall conclusion of this study was that children and adults shared the same sentenceparsing mechanism, although with a slightly different time course of operation.

Furthermore, in a study conducted by N. Witzel, Witzel, and Forster (2012), four different methods of examining online sentence processing during reading, namely self-paced, non-cumulative, moving window reading, eye tracking, and two kinds of maze task - lexicality and grammaticality maze were compared in the processing sentences with structural ambiguities. Despite some overlap in the general results, obvious differences were observed among these methods in terms of the strength of timing of the observed effects. Particularly, the maze tasks both provided robust, "localized" indications of incremental sentence processing difficulty compared to self-paced reading and eye tracking except for sentences tapping into clause-closure commitments. 
There has been, however, no study stating which one of these ambiguities makes processing the most difficult, or in more general terms, if there is any significant difference between the processing problems these different kinds of ambiguities can cause, especially for L2 learners. Accordingly, this study tried to investigate the significance of the differences among three mentioned types of ambiguities in terms of the time needed to process the sentences containing them in a multiple-choice translation task. More precisely, this study was an attempt to answer the following research question:

Is there any significant difference among the process times for sentences containing lexical, grouping, or functional ambiguities in terms of processing time?

\section{Methodology}

\section{Participants}

Due to the infeasibility of random selection of the participants, the researchers employed a convenience sampling. Three intact classes with the total number of fifty-nine undergraduate EFL learners from different engineering and science majors at Sharif University of Technology participated in this study. Their proficiency level was almost the same based on their midterm and final exam test results implying that there were no outliers with quite high or quite low proficiency levels compared to peers. The recorded times for the 16 participants included outliers of two types: Firstly, some recorded times were less than 4 seconds, which seemed quite unnatural, as just reading the item and the options without any processing would take more time. Secondly, during the test some participants asked questions about how to do the task properly while their process times were recorded. Therefore, some process times seemed unnaturally big, that is more than 90 seconds. Accordingly, the recorded times of more than 90 seconds and less than 4 seconds were considered outliers. This threshold was intuitively adopted by the researchers based on the test items and their levels of difficulty. The recorded times for these 16 subjects, therefore, were eliminated from the data and the recorded times for the remaining 43 subjects were analyzed. It should also be noted that two participants were randomly selected to participate in the retrospection protocol through which the researchers aimed to probe the underlying processes participants went through while completing the task.

\section{Instruments}

The main instrument of the current study was the reaction time program of a multiple choice test of translation developed to record the process time of each item in milliseconds. There were 30 items (see the Appendix) with 3 subsections each of which consisted of 10 English sentences with one of the three different kinds of linguistic ambiguity. To put it more precisely, there 
were 10 items with lexical ambiguity, 10 items with grouping ambiguity, and 10 more items with functional ambiguity. The items were presented in a random order which was the same for all the participants. Each item was accompanied by three options: The first two options were two different Persian translations of the ambiguous sentence and the third option implied that both translations were acceptable. It is worth mentioning that half of the items were context-embedded so that just one of the given translations would be acceptable, while the other half were context-reduced giving rise to more difficulty in processing and deciding between the two translations making the third choice the acceptable one. The reaction time instrument of interest was programmed in Java, and was installed on some 20 PCs. Each item would appear on the screen and the time interval between the appearance of that item and the next item, which happened after an option that was selected by the participant, was recorded in milliseconds. It was not possible for the participants to go back to the previous items or change their selected options.

\section{Data Collection Procedure}

Three intact classes based on available sampling took the test. Prior to the test, oral instructions were given to the participants in Persian, their mother tongue. The participants were required to simply start the program and work on the test. The first item would remain on the screen until the participant clicked on one of the three options. The time interval between the appearance of each item and the moment one option was clicked on would be registered by the program in milliseconds in a separate file on each subject's PC. This procedure would recur until the participant went through all 30 items of the test. The participants were not able to go back to previous items to make any changes. The researchers would then collect the data files for later quantitative analyses of the recorded times. Using protocols shed more lights on the thought processes of the learners (see Salehi, 2011b; Salehi \& Bagheri, 2013). Through the retrospection protocol, each of the two randomly selected participants would revisit the items and their own selected options and elaborate on the reasons why they had selected that specific option and not the others. Their voices were recorded for further qualitative analyses of the thought processes they had gone through while taking the test.

\section{Results}

A multivariate ANOVA (MANOVA) was run to compare the Persian EFL learners' process times for sentences containing lexical, grouping, or functional ambiguities. It should be mentioned that the assumption of sphericity (equality of the variances of differences between tests) was met (Mauchly's $\mathrm{W}=.977, \mathrm{p}$ $>$.05) (Table 1). There was no need to modify the degrees of freedom.

Table 1. Mauchly's Test of Sphericity 


\begin{tabular}{|c|c|c|c|c|c|c|c|}
\hline \multirow[b]{2}{*}{$\begin{array}{l}\text { Within-Subjects } \\
\text { Effect }\end{array}$} & \multirow[b]{2}{*}{ Mauchly's W } & \multirow[b]{2}{*}{$\begin{array}{l}\text { Approx. Chi- } \\
\text { Square }\end{array}$} & \multirow[b]{2}{*}{ df } & \multirow[b]{2}{*}{ Sig. } & \multicolumn{3}{|l|}{ Epsilon $^{\mathrm{b}}$} \\
\hline & & & & & $\begin{array}{l}\text { Greenhouse } \\
\text {-Geisser }\end{array}$ & Huynh-Feldt & $\begin{array}{l}\text { Lower- } \\
\text { bound }\end{array}$ \\
\hline Ambi & .977 & .939 & 2 & .625 & .978 & 1.000 & .500 \\
\hline
\end{tabular}

Based on the results displayed in Table $2(\mathrm{~F}(2,84)=11.46, \mathrm{p}<.05$, Partial $\eta^{2}=.21$ representing a large effect size), it can be concluded that there were significant differences between Persian EFL learners' process times for sentences containing lexical, grouping, or functional ambiguities. Thus the null-hypothesis was rejected.

Table 2. Tests of Within-Subjects Effects

\begin{tabular}{|l|l|l|l|l|l|l|l|}
\hline \multicolumn{2}{|l}{ Source } & $\begin{array}{l}\text { Type III Sum of } \\
\text { Squares }\end{array}$ & Df & Mean Square & F & Sig. & $\begin{array}{l}\text { Partial } \\
\text { Eta } \\
\text { Squared }\end{array}$ \\
\hline \multirow{4}{*}{ Ambi } & $\begin{array}{l}\text { Sphericity } \\
\text { Assumed }\end{array}$ & 19147791369.504 & 2 & 9573895684.752 & 11.461 & .000 & .214 \\
\cline { 2 - 9 } & $\begin{array}{l}\text { Greenhouse- } \\
\text { Geisser }\end{array}$ & 19147791369.504 & 1.956 & 9790659566.514 & 11.461 & .000 & .214 \\
\cline { 2 - 9 } & Huynh-Feldt & 19147791369.504 & 2.000 & 9573895684.752 & 11.461 & .000 & .214 \\
\cline { 2 - 9 } & Lower-bound & 19147791369.504 & 1.000 & 19147791369.504 & 11.461 & .002 & .214 \\
\hline \multirow{4}{*}{$\begin{array}{l}\text { Error(A } \\
\text { mbi) }\end{array}$} & $\begin{array}{l}\text { Sphericity } \\
\text { Assumed }\end{array}$ & 70170926723.830 & 84 & 835368175.284 & & & \\
\cline { 2 - 9 } & $\begin{array}{l}\text { Greenhouse- } \\
\text { Geisser }\end{array}$ & 70170926723.830 & 82.140 & 854281860.406 & & & \\
\cline { 2 - 5 } & 70170926723.830 & 84.000 & 835368175.284 & & & \\
\cline { 2 - 9 } & Lower-bound & 70170926723.830 & 42.000 & 1670736350.567 & & & \\
\hline
\end{tabular}

Note. If the assumption of sphericity was not met, any of the Greenhouse-Geisser, Huynh-Feldt or lower bound would be reported.

As displayed in Table 3, the subjects needed the least time to process lexical ambiguity $(\mathrm{M}=183537.60)$. This was followed by grouping ambiguity $(\mathrm{M}=207296.93)$ and the most difficult one, functional ambiguity $(\mathrm{M}=$ 211055.90).

Table 3. Descriptive Statistics

\begin{tabular}{|l|l|l|l|l|}
\hline \multirow{2}{*}{ Ambi } & \multirow{2}{*}{ Mean } & \multirow{2}{*}{ Std. Error } & \multicolumn{3}{|l|}{ 95\% Confidence Interval } \\
\cline { 4 - 6 } & & & Lower Bound & Upper Bound \\
\hline Lexical & 183537.605 & 7148.208 & 169111.937 & 197963.273 \\
\hline Group & 207296.930 & 7713.521 & 191730.414 & 222863.446 \\
\hline Function & 211055.907 & 7303.751 & 196316.341 & 225795.473 \\
\hline
\end{tabular}

Although the F-value of 11.46 (Table 2) indicated significant differences between the processing times needed for three types of ambiguity, the pairwise comparison tests had to be run to compare the processes two by two. Based on the results displayed in Table 4.4, it can be concluded that:

a. There was a significant difference between times needed for lexical (M $=183537.60)$ and grouping ambiguity $(\mathrm{M}=207296.93)(\mathrm{MD}=23759.32$, 
$\mathrm{p}<.05)$. The subjects significantly needed more time to process grouping ambiguity.

b. There was a significant difference between times needed for lexical (M $=183537.60)$ and functional ambiguity $(\mathrm{M}=211055.907)(\mathrm{MD}=$ $27518.30, \mathrm{p}<.05)$. The subjects significantly needed more time to process functional ambiguity.

Table 4. Pairwise Comparisons

\begin{tabular}{|l|l|l|l|l|l|l|}
\hline & & $\begin{array}{l}\text { Mean } \\
\text { Difference } \\
\text { (I) Ambi }\end{array}$ & \multirow{2}{*}{ Std. Error } & \multirow{2}{*}{ Sig. } & \multicolumn{2}{|l|}{$\begin{array}{l}\text { 95\% Confidence Interval for } \\
\text { (J) Ambiference }\end{array}$} \\
\cline { 5 - 7 } & (I-J) & & & Lower Bound & Upper Bound \\
\hline Group & Lexical & $23759.326^{*}$ & 6683.900 & .003 & 7091.902 & 40426.749 \\
\hline \multirow{2}{*}{ Function } & Lexical & $27518.302^{*}$ & 6035.160 & .000 & 12468.620 & 42567.985 \\
\cline { 2 - 7 } & Group & 3758.977 & 5955.277 & 1.000 & -11091.502 & 18609.456 \\
\hline
\end{tabular}

*. The mean difference is significant at the .05 level.

C: There was not any significant difference between times needed for grouping $(\mathrm{M}=$ 207296.930) and functional ambiguity $(M=211055.907)(M D=3758.97, p>.05)$.

\section{Discussion and Conclusion}

Based on the descriptive analysis of the data, lexical ambiguity turned out to need the least amount of processing time followed by grouping and functional ambiguities, respectively. In other words, lexical ambiguity was the easiest type of ambiguity to be processed, while functional ambiguity was the most difficult one. However, the difference between grouping and functional ambiguity was not significant which can be due to the fact that grouping ambiguity and functional ambiguity are two different types of structural ambiguity. Accordingly, the only plausible claim would be to imply that lexical ambiguity takes less processing time compared with structural ambiguity. This is what one may intuitively hypothesize to be the case. In the case of lexical ambiguity, participants simply have to deal with two meanings of one word one of which in many cases is quite dominant in terms of frequency of use. In the context-embedded instances, this is even more straightforward, because despite the frequency of use, the context leads participants to activate only one meaning of a potentially ambiguous word. In the case of structural ambiguity, on the other hand, participants have to deal with two different structures each giving rise to one potential meaning, which seems to be a more demanding task. This was quite obvious in the retrospection protocol, as the two selected participants did not seem to have much difficulty in coming up with the correct option in case of the lexically ambiguous sentences, while they put more time into making sense of the structurally ambiguous sentences.

One interesting point about the thought processes of the two participants taking part in the retrospection protocol was that both of them selected the options that would seem more plausible and realistic. Even in context-reduced examples where the two given translations would be acceptable, they claimed that one of the translations, which was quite odd and unlikely to be the correct 
one. This might have to do with the fact that the more frequent and realistic the meaning is, the more automatically it is activated.

The focus of this study was mainly on the recorded times for each participant. Further research could dig into the options selected by each participant and have more participants take part in the retrospection protocol. This would certainly enrich the results and explain why this difference exists between lexical and structural ambiguities.

One of the limitations of this study is the fact that the participants were all undergraduate students of science and engineering. Accordingly, the findings of the current study may not generalize to other groups of people including those with different ages or different educational backgrounds. This puts the external validity of this study into question. Random selection, on the other hand, was not feasible and the researchers were obliged to use convenience sampling; using intact classes of general English may jeopardize the internal validity of this study.

The findings of this study can contribute to the previous studies conducted regarding ambiguity and grammaticality judgment, in general, and provide a relatively precise comparison among the three main categories of the linguistic ambiguities, namely lexical, grouping, and functional ambiguities. Since ambiguities are a major source of miscommunication, especially among learners of a second or foreign language, it is important to educate learners about the ambiguities they may encounter. The results of the current study give us some reliable insights as to which kind of the three major ambiguities in English causes a heavier processing load for learners of English as a foreign language. This can be useful when it comes to educating English learners about ambiguities, and deciding which ambiguity warrants more focus and attention.

\section{References}

Akmajian, A., Demers, R., Farmer, A., \& Harnish, R. (2001). Linguistics: An introduction to language and communication. Cambridge, Massachusetts: The MIT press.

Altmann, G. (1998). Ambiguity in sentence processing. Trends in Cognitive Sciences, 2(4), 146-152.

Boada, R., Sánchez-Casas, R. M., Gavilán, J. M., García-Albea, J. E., \& Tokowicz, N. (2013). Effect of multiple translations and cognate status on translation recognition performance of balanced bilinguals. Bilingualism: Language and Cognition, 16, 183-197.

Degani, T., \& Tokowicz, N. (2010). Ambiguous words are harder to learn. Bilingualism. Language and Cognition, 13, 299-314.

Duffy, S. A., Morris, R. K., \& Rayner, K. (1988). Lexical ambiguity and fixation times in reading. Journal of Memory and Language, 27(4), 429-446.

Eddington, C. M., \& Tokowicz, N. (2013). Examining English-German translation ambiguity using primed translation recognition. Bilingualism: Language and Cognition, 16, 442-457.

Forster, K. I., Guerrera, C., \& Elliot, L. (2009). The maze task: Measuring forced incremental sentence processing time. Behavior Research Methods, 41(1), 
163-171.

Fromkin, V., Rodman, R., \& Hyams, N. (2013). An introduction to language. Wadsworth Publishing. Boston: Cengage Learning.

Garrett, M., Bever, T., \& Fodor, J. (1966). The active use of grammar in speech perception. Perception \& Psychophysics, 1(1), 30-32.

Hudson, G. (1999). Essential introductory linguistics. Cambridge, Mass: Blackwell Publishers.

Just, M. A., Carpenter, P. A., \& Woolley, J. D. (1982). Paradigms and processes in reading comprehension. Journal of Experimental Psychology: General, $111(2), 228$.

Joseph, H. S., \& Liversedge, S. P. (2013). Children's and adults' on-line processing of syntactically ambiguous sentences during reading. PloS one, 8(1), e54141.

Kail, M., Lemaire, P., \& Lecacheur, M. (2012). Online grammaticality judgments in French young and older adults. Experimental Aging Research, 38(2), 186-207.

Kamide, Y., Altmann, G., \& Haywood, S. L. (2003). The time-course of prediction in incremental sentence processing: Evidence from anticipatory eye movements. Journal of Memory and Language, 49(1), 133-156.

Laxén, Jannika, \& Lavaur, Jean-Marc (2010). The role of semantics in translation recognition: Effects of number of translations, dominance of translations and semantic relatedness of multiple translations. Bilingualism: Language and Cognition, 13, 157-183.

MacKay, D. C. (1996). Ambiguity, language, and cognition: Retrospect and prospect. Retrieved from http://bit.ly/1MhojkT.

Mackey, A., \& Gass, S. M. (2005). Second language research: Methodology and design. New York: Routledge.

Papadopoulou, D. (2005). Reading-time studies of second language ambiguity resolution. Second Language Research, 21(2), 98-120.

Piantadosi, S. T., Tily, H., \& Gibson, E. (2012). The communicative function of ambiguity in language. Cognition, 122(3), 280-291.

Salehi, M. (2011a). The acquisition of pied piping and preposition stranding by Persian learners of English. Iranian EFL Journal, 7 (3), 85-100.

Salehi, M. (2011b). Test taking strategies: Implications for test validation. Journal of Language Teaching and Research, 2 (4), 850-858.

Salehi, M., \& Bagheri Sanjareh, H. (2013). On the comparability of C-test and cloze test: A verbal protocol approach. English for Specific Purposes World, 14(39).

Salehi, M., \& Bagheri Sanjareh, H. (2014). What is the impact of response format on validating grammaticality judgment tests? Journal of Teaching English Language and Literature Society of Iran, 8(1), 91-120.

Seidenberg, M. S., Tanenhaus, M. K., Leiman, J. M., \& Bienkowski, M. (1982). Automatic access of the meanings of ambiguous words in context: Some limitations of knowledge-based processing. Cognitive Psychology, 14(4), 489537.

Sheridan, H., \& Reingold, E. M. (2012). The time course of contextual influences during lexical ambiguity resolution: Evidence from distributional analyses of fixation durations. Memory \& Cognition, 40(7), 1122-1131.

Simpson, G. B. (1981). Meaning dominance and semantic context in the processing of lexical ambiguity. Journal of Verbal Learning and Verbal Behavior, 20(1), 120-136.

Snedeker, J., \& Yuan, S. (2008). Effects of prosodic and lexical constraints on parsing in young children (and adults). Journal of Memory and Language, 58(2), 574- 
608.

Tokowicz, N. (2014). Translation Ambiguity Affects Language Processing, Learning, and Representation. Retrieved from http://bit.ly/1X1T7ch.

Tokowicz, N., \& Kroll, J. F. (2007). Number of meanings and concreteness: Consequences of ambiguity within and across languages. Language and Cognitive Processes, 22, 727-779.

Waters, G. S., \& Caplan, D. (2004). Verbal working memory and on line syntactic processing: Evidence from self paced listening. Quarterly Journal of Experimental Psychology Section A, 57(1), 129-163.

Witzel, N., Witzel, J., \& Forster, K. (2012). Comparisons of online reading paradigms: Eye tracking, moving-window, and maze. Journal of Psycholinguistic Research, 41(2), 105-128. 


\section{Appendix}

1. I looked everywhere, but I didn't see the glasses.

a) ..., but I didn't see the window glasses.

$$
\begin{aligned}
& \text { الف) ...، اما شيشه ها را بيدا نكردم. } \\
& \text { ب) .... اما عينك را بيدا نكردم. }
\end{aligned}
$$

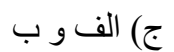

b) ..., but I didn't see the eyeglasses.

c) $a \& b$

2. Smoking cigars can be dangerous, you shouldn't through them out of the window.

a) When being smoked, cigars can be dangerous, .... .

$$
\text { الف) سيخار روشن مى تو اند خطر آفرين بانثد،.... . }
$$

b) It can be dangerous to smoke cigars, ... .

$$
\text { ب) سيحار كثيدن مى نو اند خطرناك باثد، ... . . }
$$

c) $a \& b$

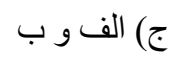

3. John is too far away to see.

a) John is so far that he cannot be seen.

b) John is so far that he cannot see.

c) $a \& b$

$$
\text { الف) جان آنقدر دور است كه نمى شود او را ديد. }
$$$$
\text { ب) جان آنقر دور است كه نمى تو اند بيبند. }
$$

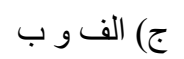

4. The boy saw the man with the telescope.

a) The boy saw the man through the telescope.

الف) آن يُر بوسيله تلسكوبٍ آن مرد را ديد. ب) آن بِسر مردى كه تلسكوب داشت را ديد.

b) The boy saw the man who had a telescope.

c) $a \& b$

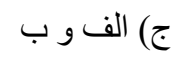

5. They went to the bank on their family vacation.

a) They went to the bank (financial institute) ... .

b) They went to the beach ... .

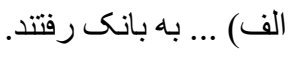$$
\text { ب) (ب) (ب) به ساحل رفتند. }
$$

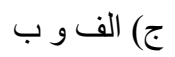

c) $a \& b$

6. He read the paper that he received from the journal yesterday.

$$
\text { الف) او مقاله اى را خو اند كه ديروز از مجلّه كَرفته بود. }
$$

a) He read the paper which he had yesterday received from the journal.

b) Yesterday he read the paper he had received from the journal.

c) $a \& b$

$$
\text { ب) او ديروز مقاله اى كه از مجلّه كَرفته بود را خو اند. }
$$

7. I like ice cream more than you, since I have never seen you to be in the mood for ice cream.

a) I like ice cream more than I like you, ... .

$$
\text { الف) من بستتى را به تو ترجيح مى دهم،... . }
$$

$$
\text { ب) علاقه من به بستنى بيشتر از علاقه تو به بستنى است،... . }
$$


b) I like ice cream more than you do, ... .

c) $a \& b$

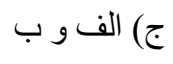

8. He strips the bark and leaves.

a) He strips the bark as well as the leaves.

$$
\text { الف) او بوست و برخ درخت هار ا مى كند. }
$$

b) He strips the bark and goes away.

c) $a \& b$

$$
\text { ب) او يوست درخت ها را مى كندو از آنجا مى رود. }
$$

9. The girl in the car that needed water is waiting, but we won't find any drinkable water.

$$
\text { الف) دخترى كه در ماثنين است و آب مى خو اهد منتظر است،... . }
$$

a) The girl in the car who needed water is waiting, .... .

$$
\text { ب) دخترى كه در مانثينى است كه به آب احتياج دارد منتظر است،... . }
$$

b) The girl in the car which needed water is waiting, ... .

c) $a \& b$

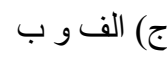

10. The duck is too hot to eat, let it cool down.

a) The duck is so hot that it cannot be eaten, ... .

b) The duck is so hot that it cannot eat, ... .

$$
\text { ب) اردى آنقدر كَرمش است كه نمى نو اند غذا بخورد، ......... }
$$

c) $a \& b$

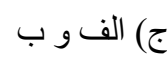

11. The professor gave me a paper, and asked me to make a copy of it.

a) The professor gave me a piece of paper, .... .

b) The professor gave me an article, ... .

c) $a \& b$

الف) استاد بركه اى را به من داد، .... . ب) (استاد مقاله اى را به من داد، ....

12. I told him to turn right there, but he turned left instead.

a) I told him to turn to the right side there, ... . الف) به او كفتم كه آنجا به راست بيجيجد، ... .

b) I told him to turn right exactly there, ... . ب) به او كفتم دقيقاً همانجا بيبجد، ... . .

c) $a \& b$

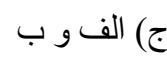

13. The spring is over there; you can take it.

a) The fountain is over there; ... .

b) The metal spring is over there; ... .

c) $a \& b$

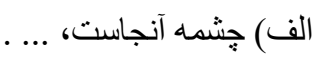

14. Writing exercises can be very difficult for the students.

$$
\text { الف) نوشتن تمرين مى تو اند براى دانش آموزان خيلى سخت بانثد. }
$$

a) It can be very difficult for the students to write the exercises.

$$
\text { ب) تمرين هاى نحارشى مى تو انند بر اي دانش آموز ان خيلى سخت بانشند. }
$$

b) It can be very difficult for the students to do the writing exercises. 
c) $a \& b$

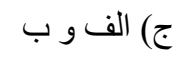

15. They are hunting dogs, even though it is illegal.

a) They are dogs used for hunting, ... . الف) آنها سگ هاى شكارى هستند، ... . .

b) They are trying to hunt dogs, ... . ب) آنها سع شكار مى كنند، .... c) $a \& b$

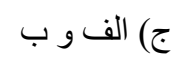

16. The teacher asked them how they found the book.

$$
\text { الف) معلم از آنها بِرسيد كه جطور كتاب را بِيدا كرده اند. }
$$

a) The teacher asked them how they could find the book.

b) The teacher asked them how they liked the book.

c) $a \& b$

$$
\text { ب) معلم از آنها يرسيد كه نظرشان در مورد كتاب جِيست. }
$$

17. I understand money matters.

a) I understand financial matters.

b) I understand that money is important.

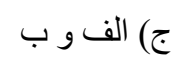

c) $a \& b$

18. Tom is too proud to love; no one seems to care about him except his family.

a) Tom is so proud that no one can like him;... .

$$
\text { ج) ب) مى دانف از مسائل مالى سر در مى آورم. }
$$

b) Tom is so proud that he cannot like any body; ... .

c) $a \& b$

الف) تام آنقدر مغرور است كه نمى نوان او را دوست داشت؛ .... ... ب) تام آنقدر مغرور است كه نمى نو اند كسى را دوست داشته باند؛ .... . . .

19. The pen seems empty, because you cannot hear the animals.

a) The pen (the writing instrument) seems empty, ... .

$$
\text { الف) به نظر مى رسد خودكار تمام شده بانثد، .... . . }
$$

b) The barn seems empty, ... .

$$
\text { ب) به نظر مى رسد آغل حيو انات خالى باثند، ......... }
$$

c) $a \& b$

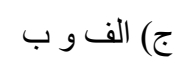

20. The problem is that he loves the car more than his wife.

الف) مشكل اينجاست كه مانشين را به همسرش ترجيح مى دهد.

a) The problem is that he loves the car more than he loves his wife.

ب) مشكل اينجاست كه علاقه او به مانثين از علاقه همسرش به مانثين بيشتر است.

b) The problem is that he loves the car more than his wife does.

c) $a \& b$

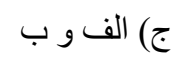

21. Two cars were reported stolen by a local yesterday.

a) A local reported two stolen cars yesterday.

$$
\text { الف) ديروز يك فرد محلى دو مانشين دزدى را كَز ارش كرد. }
$$

$$
\text { ب) ديروز دو ماثين كه توسط يك فرد محلى دزديده شده بودند كز ارش شدند. }
$$

b) Two cars stolen by a local were reported yesterday.

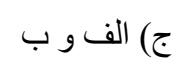


c) $a \& b$

22. I need a criminal lawyer to work on my case.

a) I need a lawyer who is a criminal, ... .

b) I need a criminal defence lawyer, ... . الف) به يك وكيل مجرم نياز دارم ....

c) $a \& b$ ب) به يكى وكيل جنايى نياز دارم ... .

23. The shooting of hunters was scary to look at.

$$
\text { الف) نحاه كردن به تير اندازى شكارجى ها ترسناك بود. }
$$

a) It was scary to look at the hunters who were shooting.

b) It was scary to look at the hunters being shut.

$$
\text { ب) نحاه كردن به تير اندازى كردن به شكارجى ها ترسناك بود. }
$$

c) $a \& b$

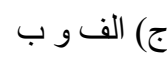

24. Annoying people can be immoral, even if you don't have the intention to hurt their feelings.

a) Those who annoy people can be immoral, ... .

b) It can be immoral to annoy people, .... .

$$
\text { ب) اذيت كردن مردم مى نو اند كارى غير اخلاقى باثد، ... . . }
$$

c) $a \& b$

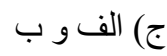

25. When I was flipping through the book, I ran into some notes.

a) ..., I ran into some written records.

b) ..., I ran into some music notes.

الف) .... به يك سرى يادداشت برخوردم.

c) $a \& b$

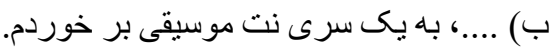

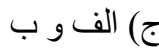

26. She is too kind to hurt; every one seems to have a tendency to treat her well.

a) She is so kind that she cannot hurt any one; ... .

$$
\text { الف) آنقدر مهربان است كه به كسى صدمه نمى زند؛ .... }
$$

$$
\text { ب) آنقدر مهربان است كه كسى دلش نمى آيد به او صدمه بزند؛ .... .... }
$$

b) She is so kind that no one wants to hurt her;

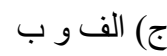

c) $a \& b$

27. He saw that gas can explode, so he called the fire station.

a) He realized that gas is explosive, ... .

b) He saw the gas container explode, ... .

الف) متوجه شد كه ممكن است بنزين مشتعل شود، ...

c) $a \& b$

ب) (بد كه قوطى بنزين منفجر شد، ... - .

28. My friends picked up a date; the wedding ceremony will be in summer.

a) My friends picked up a date (the fruit); ... .

الف) دوستانم خرما برداشتند؛ ... . .

b) My friends picked up a time; ... .

ب) دوستانم تاريخ را تعيين كردند؛ ... .

c) $a \& b$

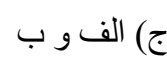


29. The child looked at the dog with one eye, and asked her dad what happened to the dog's eye.

a) With one eye, the child looked at the dog, ...

الف) كو دك يك جشمى به سگ نحاه كرد، ...

ب) كودك به سحى كه يك جشم داشت نحاه كرد، .... . . .

b) The child looked at the dog that had one eye, ... .

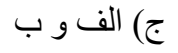

c) $a \& b$

30. They have been trying to lock him up for ten years, but his lawyer is trying to make it five years.

a) It has been ten years that they are trying to lock him up, ... .

ب) مى خو اهند او را بمدت ده سال زندانى كنند، .... . .

b) They have been trying to sentence him to ten years in prison, ... .

c) $a \& b$

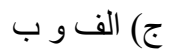


